Studia nad Autorytaryzmem i Totalitaryzmem 43, nr 4 Wrocław 2021

https://doi.org/10.19195/2300-7249.43.4.39

\author{
RENATA KUSIAK-WINTER \\ ORCID: 0000-0002-8202-1360 \\ University of Wrocław \\ renata.kusiak-winter@uwr.edu.pl
}

\title{
The constitutionalization of administrative law as a remedy for authoritarian rule: The case of Poland and the case of Germany
}

\begin{abstract}
The The continuity of the administrative apparatus is an indispensable element of any state, be it a democracy or an authoritarian regime. Given that permanency is an attribute of administration, any change from authoritarianism to democracy must therefore be followed by finding adequate corrective measures to transform public administration accordingly. In post-war Germany, it was the constitutionalisation of administrative law that had the pivotal role in attaining this goal. The paper aims at shedding more light on how to view and critique the Polish departure from the administration of the PRL-era authoritarian system in the context of the path followed by Germany.
\end{abstract}

Keywords: constitutionalisation, administrative law, administration of PRL, Germany.

\section{Introduction}

State identity evolves from the continuity of administration - the state's backbone, and the belief that the administrative routine is a vital prerequisite to stability and permanency. ${ }^{1}$ Indeed, this form of continuity does not exist in the two other branches of the tripartite separation of powers. While parliaments operate on a periodic basis and courts of law rule on specific and individual matters, the administrative body of the executive branch appears unique in its continuity. The phenomenon emerges when a political system, a government or a constitution changes. Therefore, in the historical perspective, the enduring and

1 J. Jeżewski, "O wartości biurokracji (uwagi na tle poglądów w nauce administracji we Francji)”, [in:] Biurokracja, ed. J. Łukasiewicz, Rzeszów 2006, s. 252. 
stable administration was directly linked to the traditions of statehood, which in academic discourse, found its expression recognising the autonomy of administrative law in relation to constitutional law. Otton Mayer is famously and frequently quoted as saying, "Verfassungsrecht vergeht, Verwaltungsrecht besteht" [Constitutions come and go, administrative law remains], an observation made in 1924, thereby suggesting that the civil servants of the Weimar Republic would duly apply and enforce the law of the emperor. To be precise, German administrative lawyers of the day were not isolated in their views. It is suffice to refer to one of the French classics, Alexis de Tocqueville. ${ }^{3}$ The all-important, fundamental difference between the German experience and the French one emerged in the further course of history. France eventually escaped the rule of an authoritarian regime, whilst Hitler's seizure of power entailed the building of the uncompromising and ruthless bureaucracy of a totalitarian state.

The starting point for these deliberations is the following claim: if administration has a quality of permanency, finding an adequate remedy to effectively restructure the public administrative apparatus is vital when an authoritarian system of government changes into a democracy. Post-war Germany acknowledged the key importance of the processes of constitutionalisation of administrative law, with the supreme law seen as the key instrument to shape the reality of administration. The paper aims at shedding more light on forming a critical opinion on the Polish departure from the administration of the PRL-era authoritarian system in the context of the path followed by Germany. Bearing in mind that the success of the 1989 systemic transformation is highly dependent on how the ground for constitutionalisation processes was originally laid, it is also essential to uncover the historical roots of the correlations between administrative law and constitutional law.

\section{The notion of constitutionalisation}

The phenomenon of constitutionalisation is by no means the province of administrative law only. Constitutionalisation applies to the whole legal system, and as such, it should be viewed from two perspectives in terms of its meaning: static or dynamic. The former, which apparently is the most common meaning, indicates that constitutionalisation occurs when a procedural norm is incorporated into the state's supreme law and the status of such a norm being consequently elevated to the constitutional standard. The constitutionalising of concrete norms of any law falling below the supreme law in the hierarchy is reviewed and analysed with

2 O. Mayer, Mayer O., Deutsches Verwaltungsrecht, vol. 1, Berlin 1924.

3 "C'est que,depuis [17]89, la constitution administrative est toujours resté edebout au milieu des ruines des constitutions politiques" - A. de Tocqueville, L'Ancien Régime et la Révolution, Paris 1856, p. 297. 
this very meaning in mind, for example, the proposal to constitutionalise the right to good administration. ${ }^{4}$ The perspective is static in the sense that it shows the existing and/or desired status of a given law. A law is thus equated with the content of the constitution, whereas the latter is viewed as a biding normative legal act.

This paper tackles constitutionalisation from the dynamic perspective, with its key determinants being development, processes and changes arising from the continuous implementation of the constitution. Constitutionalisation manifests itself in the gradual implementation of constitutional legal norms into the legal system, which results in the restructuring of national ${ }^{5}$ or European ${ }^{6}$ and/ or international ${ }^{7}$ norms. For the purpose of this paper, the discussion will mainly concentrate on constitutional implications of the entire legal order being focused on the enforcement of the overriding norms and values enshrined in the supreme law. ${ }^{8}$ It should be noted that the enactment of a constitution marks but the starting point of the process. In all states, constitutionalisation is in fact driven by judicial law-making (in constitutional courts, administrative courts and courts of law) and the contributions to the doctrine of law. These two weigh and differentiate among general constitutional and legal principles to subsequently develop and align the interpretation of law and ensure that it best responds to the everchanging needs and challenges of the administrative branch. ${ }^{9}$

As regards the constitutionalisation of administrative law, it should be noted that of all the fields of law, this particular one maintains a rather intense and not unreciprocated relation with constitutional law. ${ }^{10}$ In view of the subject matter of this discussion, it appears essential to sketch in historical background to understand the reasons why the constitutionalisation of administrative law should be studied, examined and addressed as a separate problem. In the past, the enactment of a constitution did not entail that constitutional law should automatically govern administrative law. On the contrary, both the German doctrine ${ }^{11}$ and the Polish doctrine ${ }^{12}$ would indicate that the transformation of a police state administration

4 O. Şaramet, "The right to good administration - is the constitutional regulation necessary?", Law Review: Judicial Doctrine \& Case-Law, 10, 2019, special issue, pp. 88-100.

5 J. Człowiekowska, "Administrative law and constitutional law", [in:] Integrity of Administrative Law: Polish Perspective, ed. J. Zimmermann, Warszawa 2019, p. 166 ff.

${ }^{6}$ F. Wollenschläger, "Constitutionalisation and deconstitutionalisation of administrative law in view of Europeanisation and emancipation", Review of European Administrative Law 10, 2017, no. 1, pp. 7-79.

7 M. Barnard, "Constitutionalising a human right to water in the Southern African development community", Utrecht Law Review 16, 2020, no. 2, p. 61.

${ }^{8}$ H. van Eijken, EU Citizenship and the Constitutionalisation of the European Union, Groningen 2015, p. 18.

9 F. Wollenschläger, op. cit., p. 32.

10 J. Człowiekowska, op. cit., p. $166 \mathrm{ff}$.

11 O. Mayer, op. cit, p. 13. W. Jellinek, Verwaltungsrecht, Berlin 1928.

12 T. Bigo, Prawo administracyjne. Część ogólna (stenogram wykładów uniwersyteckich), Lwów 1932, p. 4. 
into the rule-of-law administration was a prerequisite for administrative law to be established as a separate branch. In other words, from the historical perspective, it was the administrative law rather than the constitutional one that offered effective safeguards against the lawlessness of civil servants. It did so by binding the administrative apparatus by law and endow the individual with legal subjectivity.

\section{Germany}

The experience of the totalitarian Nazi regime urged the post war constitution-maker to raise the fundamental human rights to the rank of the primary measure of all administrative activities. The symbolism and prominence of article 1.1 of the Basic Law for the Federal Republic of Germany (Grundgesetz) could not be more explicit: "Human dignity shall be inviolable" (Die Würde des Menschen ist unantastbar). Once enshrined in the constitution, universal human values were set to shape and permeate the whole legal order, but the effect they produced on administrative law led to a crucial, historic breakthrough to the extent that with general approval administrative law was made known as concretised constitutional law. ${ }^{13}$

The Basic Law of 1949 was a consequence of the "zero hour" adopted for the purpose of the state and law in order to make a fresh start and determine both the directions of law-making and the development of modern administration. The permanency and historical continuity of administration was not any more available to administrative law or the doctrine to draw on. The new constitution became the guarantor of the stability and continuation of the administrative apparatus, especially, considering the views of certain prominent and renown administrative lawyers who had had sympathies towards the Nazi regime (dehistorization). ${ }^{14}$

The fact that the "zero hour" was adopted sheds new light on Robert von Mohl's concept of the rule of law (Rechtsstaat). ${ }^{15}$ One of the main postulates of his theory was the hierarchical order of legal acts although there appeared to be no proposal to apply the constitution directly or present the courts with measures to test the compliance of parliament acts with the supreme law. Firmly embedded in the 19th century's dominant philosophy of legal positivism, the concept of the rule of law would revolve around the act of Parliament, which presumably encouraged Otto Mayer, a leading administrative lawyer, to call the rule of law

13 F. Werner, "Verwaltungsrecht als konkretisiertes Verfassungsrecht", Deutsches Verwaltungsblatt 1959, p. 528.

14 B. Schindler, "Verwaltungsrechtswissenschaft und Geschichtsschreibung Narrative über Vergangenes - Versuch einer Typologie", Zeitschrift für Verwaltungsgeschichte 1, 2016, p. 63.

15 R. von Mohl, Die deutsche Polizeiwissenschaft nach den Grundsätzen des Rechtsstaats, Tübingen 1833, p. 8 . 
"the state of organised administrative law," 16 where administrative law was the sole assurance given to the individual of the effective legal protection against lawless administration. This is how the Basic Law created a new caesura in 1949 for the purpose of the new administration, which was programmed to actively implement human rights.

Fundamental rights did not radiate through the whole legal order automatically. It was the constitutional right to the courts that became the essential instrument in the hands of the individual and consequently increased the importance of the role played by the judiciary. The Bundesverfassungsgericht (Federal Constitutional Court) should be credited with the law-making effort that has consistently enhanced the special status of the protection of human dignity as an unrestricted provision and an element of the constitutional identity. ${ }^{17}$ Except for the sacrosanct (unantastbar) essential core of rights (Wesensgehalt der Grundrechte) (article 19.2 Basic Law), no other provision is afforded this absolute protection. Human dignity and the essential core of rights have primacy for historical reasons. The cause lay in the fiasco of the Weimar Republic, which affected the public's trust in the majority government and helped extend the influence of the judiciary. ${ }^{18}$ However, the other constitutional rights and freedoms are relative by nature and therefore relatively protected as "inviolable and inalienable" (unverletzlich und unveräusserlich). ${ }^{19}$

With the whole legal order revolving around the protection of human dignity and the essential core of rights originating in the Basic Law, it was the right of the individual [to have recourse] to the courts and the leading role of the Bundesverfassungsgericht in steering a steady course through the process of constitutionalising the whole legal system, which accounted for the profound transformation of the public administration in the spirit of the human right ideology. It is important to bear in mind that the intended dehistorisation of the German administrative processes did not prevent the main achievements of the 19th century administrative law doctrine from remaining vital and relevant. On the contrary, having been subject to continuous development and additional improvements, they made modern German law and the administration that relies and depends thereon resilient and adaptable. ${ }^{20}$

16 O. Mayer, op. cit., p. 58.

17 D.P. Currie, The Constitution of the Federal Republic of Germany, Chicago 1994, p. 288.

18 J. Śledzińska-Simon, Analiza proporcjonalności ograniczeń konstytucyjnych praw $i$ wolności. Teoria i praktyka, Wrocław 2019, p. 47.

19 Ibidem, p. 54.

20 The development of the principle of proportionality seems a perfect example. The principle is not stipulated in German Basic Law, but through the case-law of the Bundesverfassungsgericht has become a commonly applied standard when assessing the restrictions of constitutional rights and freedoms. The principle was originally worked out basing on the case-law of the Prussian administrative court and the German public law doctrine in the second half of the 19th century. See 


\section{Poland}

From a historical perspective, the relationship between administrative law and constitutional law is the product of the link between the administrative apparatus and the state. With the absence of Polish statehood during the entire 19th century when Continental Europe's administrative law was in the making, the genetic binding between the state and the administration was naturally broken. It should be emphasized that in these specific circumstances, foreign administrative laws became key integration agents, as their best models came under the close scrutiny of Poland's administrative lawyers after the country regained independence in 1918. What makes this foreign trait important is the fact that the models would not offer any reasonable adequate mechanisms to effectively implement constitutional norms even though the two Polish constitutions which were passed in the during the twenty year period between the two world wars - the 1921 March Constitution and the 1935 April Constitution - played a part in strengthening the sense of the state's identity. Nonetheless, like their West European counterparts, they failed to provide any possibility of applying constitutional clauses directly or offer any tests that the judiciary might have employed to verify the compliance of statutes with the supreme law. ${ }^{21}$

The PRL era was a contradiction in terms of any standards of the effective protection of human rights in the administrative practice. The 1956 constitution established the system of a people's democracy, with the primary focus on the methods of ruling and governing. They were reflected in two principles: the leading role of the workers' party and centralised democracy. ${ }^{22}$ Saturated with ideology and set in the open system of sources of law, the constitution unsurprisingly failed to show any qualities enabling consolidation or integration. The scholarly research was unable to lend any support to it either, especially, in the area of axiology. As regards administrative law, one cannot fail to notice the role of those who contributed to the doctrine. Except for the era of Stalin's dictatorship, scholars would normally engage in close studies of administrative law and produce the research that afforded valuable insights. The ritualistic hailing of the socialist system's supremacy over the rest of the world would generally satisfy the servitude arrangements with the political system that otherwise did not restrain researchers as they embarked on their scholarly state-of-the-art

K.F. Ledford, "Formalizing the rule of law in Prussia: The Supreme Administrative Law Court, 1876-1914", Central European History 37, 2004, p. 203.

${ }^{21}$ Ch. Möllers, "Pouvoir constituant — constitution — constitutionalisation", [in:] Principles of European Constitutional Law, eds. A. Bogdandy, J. Bast, Oxford-Portland-Oregon 2006, p. 216.

22 J.J.F. Morrison, The Polish People's Republic, Baltimore 1968. 
analyses of the existing legislation. ${ }^{23}$ The doctrine benefited from the contributions of the top echelons of the pre-war academia, with Franciszek Longchamps de Bérier among them. His ground-breaking work on the latest research developments in West European administrative law discussed the situation of man in relation to the administrative apparatus. ${ }^{24}$ On the one hand, unlike the established traditional doctrine that mainly dealt with the rights of a citizen rather that an individual, it pursued a new approach. On the other hand, it launched a silent critique of the authoritarian system by citing the best solutions adopted in European democracies.

Following the reinstatement of the institutions of administrative justice (1980) and the establishment of the Constitutional Tribunal (1985), the 1980s saw the institutional framework of constitutionalisation improve. However, the aim was to protect the existing regime rather than the rights and freedoms of the individual. It was not until the principle of the rule of law took its proper shape in the transformation of the system in 1989 that the need to protect the addressees of the norms increased. After all, it is they who put the construction on the processes of constitutionalisation. The presently-binding Constitution of the Republic of Poland was enacted in 1997. This fact makes the Polish experience unique in the context of the West European administrative solutions. The Polish Constitution was tailored to meet the needs and expectations of the 21 st century. On the one hand, it is designed to redress and right the losses and wrongs done by the authoritarian system, while on the other hand, it prompts the public administration to break away in a move ahead of the others and avoid the errors committed elsewhere. Above all, the constitution should be the main tool to restore and normalise the relationship between the public authority and the individual. In fact, any pressing demand to ensure the effective protection of human right is symptomatic of the degenerated rule of an authoritarian regime. ${ }^{25}$

\section{Conclusion}

The following remarks emerge with the comparison of the restructuring of the administrative system in Poland and the constitutionalisation processes in Germany. Firstly, with the lack of continuity of the Polish state and the dominance of the externally imposed communist ideology, what dominated the public debate

23 I. Lipowicz, "Einfluss des deutschen Verwaltungsrechts auf die Lehre des Verwaltungsrechts in Polen", Die Verwaltung 48, 2015, no. 3, p. $369 \mathrm{ff}$.

24 F. Longchamps de Bérier, Wspótczesne kierunki rozwoju nauki prawa administracyjnego na Zachodzie Europy, Wrocław 2001.

25 W. Sadurski, Rights before Courts: A Study of Constitutional Courts in Postcommunist States of Central and Eastern Europe, Berlin 2005. 
after the re-establishment of sovereignty was the need to draw on the best Polish traditions of the statehood and administration between the two world wars. Due to the liberal development and exchange of scholarly thought on the position of the individual towards the administrative apparatus, the PRL's legacy did not appear to have lost its pertinence in the process. In this sense, there is absolutely no room for the ahistorical position characteristic of the German approach that was motivated by the necessity to dissociate oneself from the legacy of the Nazi regime.

The second important element is the rank and role ascribed to human dignity in the process of constitutionalisation. It should be noted that the Polish constitution also comprises an extended catalogue of the rights of an individual. It is contained in Chapter II and divided into general principles (articles 30-37), personal freedoms and rights (articles 38-56), political freedoms and rights (articles 57-63), economic, social and cultural freedoms and rights (articles 64-76) and in aggregate accounts for almost $1 / 4$ of the content. The structure of Chapter II seemingly implies that human dignity (article 30 ) has a special status, but in reality its actual impact as one of the general principles appears to be limited. This is a consequence of the practice followed by the Constitutional Tribunal which directs all entities initiating the test to begin with invoking specific guarantees of the constitutional rights and freedoms prior to invoking more general ones. ${ }^{26}$ This practice undoubtedly reflects a different route of constitutionalisation in post-Communist Poland. On the one hand, the Constitutional Tribunal has the leading role in setting the standards for the protection of human rights, on the other hand, however, since its earliest days, the same Tribunal has in many cases acted under compulsion to construe law in favour of the state. In other words, to defend the interest of the state rather than the interest of an individual. The systematics of the layout of the constitution supports this viewpoint with article 1 stipulating, "The Republic of Poland shall be the common good of all its citizens." Notably, some opinions expressed in the literature on this subject claim that "the statist tradition in Polish constitutionalism is stronger than the civic one." 27

The assessment of the current progress towards constitutionalisation, i.e. the process of consistent strengthening of the individual's rights in relation to the administrative apparatus, reveals a clear regression, due to the fact that the institutions of the independent judiciary in Poland have been seriously undermined. Apparently, the Constitutional Tribunal has been subjected to politicization since 2015, with its current role focusing on the justification of the actions of the party that has the majority in the parliament. Let us not forget that the strong position

${ }^{26}$ A. Śledzińska-Simon, "Proportionality analysis by the Polish Constitutional Tribunal", [in:] Proportionality in Action: Comparative and Empirical Perspectives on the Judicial Practice, eds. M. Kremnitzer, T. Steiner, A. Lang, Cambridge-New York 2020, pp. 410-411.

27 B. Puchalska, Limits to Democratic Constitutionalism in Central and Eastern Europe, LondonNew York, 2011, p. 126 — quoted after: A. Śledzińska-Simon, op. cit., p. 389. 
of the Tribunal's German counterpart, i.e. Bundesverfassungsgericht, the prime mover of constitutionalising, is the product of two elements: the recognition of the fiasco of the Weimar Republic and the limitation of public trust in the ruling majority. Nonetheless, there is a disposition and power of determination to continue the processes of the constitutionalisation and protection of human rights in Poland regardless of the intense constitutional crisis. The rulings of the administrative courts and the doctrine that is tackling the axiology of administrative law with full commitment of its contributors are testimony to this.

\section{References}

Barnard M., "Constitutionalising a human right to water in the Southern African development community", Utrecht Law Review 16, 2020, no. 2.

Bigo T., Prawo administracyjne. Część ogólna (stenogram wykładów uniwersyteckich), Lwów 1932. Currie D.P., The Constitution of the Federal Republic of Germany, Chicago 1994.

Człowiekowska J., "Administrative law and constitutional law", [in:] Integrity of Administrative Law: Polish Perspective, ed. J. Zimmermann, Warszawa 2019.

Eijken H. van, EU Citizenship and the Constitutionalisation of the European Union, Groningen 2015. Jellinek W., Verwaltungsrecht, Berlin 1928.

Jeżewski J., "O wartości biurokracji (uwagi na tle poglądów w nauce administracji we Francji)", [in:] Biurokracja, ed. J. Łukasiewicz, Rzeszów 2006.

Ledford K.F., "Formalizing the rule of law in Prussia: The Supreme Administrative Law Court, 1876-1914", Central European History 37, 2004.

Lipowicz I., "Einfluss des deutschen Verwaltungsrechts auf die Lehre des Verwaltungsrechts in Polen", Die Verwaltung 48, 2015, no. 3.

Longchamps de Bérier F., Współczesne kierunki rozwoju nauki prawa administracyjnego na Zachodzie Europy, Wrocław 2001.

Mayer O., Deutsches Verwaltungsrecht, vol. 1, Berlin 1924.

Mohl R. von, Die deutsche Polizeiwissenschaft nach den Grundsätzen des Rechtsstaats, Tübingen 1833.

Möllers C., "Pouvoir constituant - constitution — constitutionalisation", [in:] Principles of European Constitutional Law, eds. A. Bogdandy, J. Bast, Oxford-Portland-Oregon 2006.

Morrison J. F., The Polish People's Republic, Baltimore 1968.

Puchalska B., Limits to Democratic Constitutionalism in Central and Eastern Europe, London-New York, 2011.

Sadurski W., Rights before Courts: A Study of Constitutional Courts in Postcommunist States of Central and Eastern Europe, Berlin 2005.

Şaramet O., "The right to good administration — is the constitutional regulation necessary?", Law Review: Judicial Doctrine \& Case-Law, 10, 2019, special issue.

Schindler B., "Verwaltungsrechtswissenschaft und Geschichtsschreibung Narrative über Vergangenes - Versuch einer Typologie", Zeitschrift für Verwaltungsgeschichte 1, 2016.

Śledzińska-Simon A., Analiza proporcjonalności ograniczeń konstytucyjnych praw $i$ wolności. Teoria i praktyka, Wrocław 2019.

Śledzińska-Simon A., "Proportionality analysis by the Polish Constitutional Tribunal", [in:] Proportionality in Action: Comparative and Empirical Perspectives on the Judicial Practice, eds. M. Kremnitzer, T. Steiner, A. Lang, Cambridge-New York 2020. 
Tocqueville A. de, L'Ancien Régime et la Révolution, Paris 1856.

Werner F., "Verwaltungsrecht als konkretisiertes Verfassungsrecht", Deutsches Verwaltungsblatt 1959.

Wollenschläger F., "Constitutionalisation and deconstitutionalisation of administrative law in view of Europeanisation and emancipation", Review of European Administrative Law 10, 2017, no. 1. 